\title{
Wybrane zagadnienia ergonomii i bezpieczeństwa w polskiej konstrukcji pojazdu PRT (Personal Rapid Transit)
}

\author{
$W$ artykule opisano istote innowacyjnego systemu transportowego PRT (Personal Rapid \\ Transit), który budzi ogromne zainteresowanie $w$ wielu krajach. Przedstawiono zagadnienia \\ ergonomii i bezpieczeństwa w polskiej konstrukcji pojazdu PRT - SITIN.
}

\section{Wstęp}

Ciagły rozwój aglomeracji miejskich pociąga za sobą konieczność zapewnienia ich mieszkańcom sprawnego miejskiego systemu transportowego. To stwierdzenie coraz częściej pozostaje jedynie niespełnionym życzeniem. Zanieczyszczenie środowiska spalinami, coraz dłuższy czas poświęcany na dojazd i powrót $\mathrm{z}$ pracy, trudności $\mathrm{w}$ przemieszczaniu się $\mathrm{w}$ obrębie miast, zwiększająca się wypadkowość w transporcie - to tylko kilka cech charakteryzujących współczesne życie w aglomeracjach miejskich. Poszukiwania nowych, innowacyjnych rozwiązań w transporcie, które poprawiłyby jakość życia, rozpoczęto już dosyć dawno.

Pomysł wykorzystania nowego środka transportu jakim jest Personal Rapid Transit (PRT) to właśnie jeden ze sposobów na rozwiązanie pojawiających się kłopotów transportowych w aglomeracjach miejskich. Idea PRT, choć nie nowa znana w krajach zachodnich od lat 60-tych, obecnie zyskuje coraz większe zainteresowanie wśród konstruktorów. Odżyła pod koniec lat dziewięćdziesiątych i na początku XXI wieku. Powstały nowe rozwiązania. Na przykład Rayteon, SkyTran, Cyber Cabs. W Europie na ukończeniu jest projekt ULTRA, który prawdopodobnie jako pierwszy wdrożony zostanie na lotnisku Heathrow (przewidywany termin wdrożenia - 2009 rok). Równie zaawansowany jest projekt koreańskoszwedzkiego konsorcjum VECTUS Ltd. System PRT ma zostać wdrożony w Upsali w 2009 roku. Rozpoczęto również prace wdrożeniowe amerykańskiego systemu SkyWeb/Taxi 2000. Tak duże zainteresowanie ideą PRT wśród konstruktorów pozwala na postawienie tezy, że PRT może stać się alternatywnym rozwiązaniem w stosunku do systemów już eksploatowanych (np. metro, tramwaj, autobus), a w perspektywie może przejać rolę transportu dominująceGø[rbłzumiemy pod pojęciem PRT?

Personal Rapid Transit (PRT) to inteligentny system transportowy, łączący cechy indywidualnego i masowego transportu miejskiego typu ,point to point” lub „door to door", na który składają się małe pojazdy (czteroosobowe) poruszające się zdalnie po lekkiej infrastrukturze - najczęściej szynie napowietrznej. Podróż odbywa się od stacji początkowej do stacji docelowej bez przystanków pośrednich.

Prace badawcze dotyczące polskiego Systemu Indywidualnego Transportu Inteligentnego $i$ Napowietrznego - SITIN - rozpoczęto w roku 2006 w ramach Uczelnianego Programu Badawczego na Politechnice Warszawskiej. System PRT - SITIN obejmuje: inteligentne pojazdy, systemy sterowania, systemy stacyjne, strukturę toru, infrastrukturę. Jest więc typowym systemem integrującym $\mathrm{w}$ sobie rozwiązania dotyczące wielu dyscyplin i obszarów techniki i nauki w tym między innymi: sterowania, konstrukcji, dynamiki, telekomunikacji, ergonomii i bezpieczeństwa [5].

Badania dotyczące ergonomii inteligentnego pojazdu obejmują zagadnienia dostosowania pojazdu do szerokiej grupy użytkowników, w tym również osób niepełnosprawnych, z punktu widzenia antropometrii, komfortu jazdy a także latwego programowania trasy jazdy i kontaktu $\mathrm{z}$ centrum sterowania systemem. Wszystkie podejmowane działania mają na celu zapewnienie bezpieczeństwa osobom korzystającym z pojazdów.

W niniejszym artykule omówione zostaną jedynie wybrane zagadnienia dotyczace ergonomii $i$ bezpieczeństwa jednego $\mathrm{z}$ elementów systemu PRT jakim jest pojazd. Ograniczenia te wynikają $\mathrm{z}$ szerokiego zakresu analizowanych zagadnień .

\section{Wymagania ogólne bezpieczeństwa projekto- wanego systemu PRT}

Podstawowe założenia przyjęte $\mathrm{w}$ badaniach polskiego systemu PRT, warunkujące wymagania bezpieczeństwa, są następujące:

1. system PRT realizowany będzie z wykorzystaniem pojazdów czteroosobowych (wymagana lekka infrastruktura) poruszających się $\mathrm{z}$ wykorzystaniem napędu elektrycznego na szynie napowietrznej,

2. pojazdy PRT muszą mieć gabaryty zgodne z wymogami ergonomicznymi oraz umożliwiać transport osób niepełnosprawnych, 
3. sieć „dróg” dla pojazdów PRT jest dwuwarstwowa i składa się z warstwy I (w skład, której wchodzą tzw. magistrale główne, po których poruszają się pojazdy ze stałą prędkością v (ok. 50 $\mathrm{km} / \mathrm{h}$ ) przy separacji 10 metrowej oraz warstwy II (w skład, której wchodzą drogi, po których pojazdy poruszaja się z mniejszą prędkością $(0-50$ $\mathrm{km} / \mathrm{h}$ i która realizuje istotę transportu ,door to door" tzn. transport pasażera od stacji początkowej do końcowej, bez przystanków pośrednich),

4. prędkość zjazdu z warstwy I do warstwy II nie powinna opóźniać ruchu na magistrali głównej oraz nie powinna powodować efektów niedopuszczalnych z punku widzenia oddziaływania niezrównoważonego przyspieszenia na człowieka oraz szybkości jego zmian tzw. ,jerk".

System PRT powinien być tak zaprojektowany i zbudowany w taki sposób, aby zapewnić

bezpieczną eksploatację przy uwzględnieniu zastosowanych rozwiązań technicznych, naturalnych i fizycznych cech terenu, na którym są one instalowane, w tym nachylenia powierzchni i różnice poziomów oraz ich otoczenia, a także czynników atmosferycznych i meteorologicznych, jak również budowli i przeszkód zlokalizowanych w pobliżu. Konstrukcja pojazdu oraz ksztalt toru powinny uwzględniać możliwość zapobiegania pojawiającym się drganiom poprzecznym i wzdłużnym, mającym negatywny wpływ na organizm pasażera.

Przy projektowaniu systemu PRT należy określić:

- Odległości pionowe i poziome między pojazdami, odległości od budowli i przeszkód położonych $\mathrm{w}$ pobliżu, na ziemi lub $\mathrm{w}$ powietrzu, zapewniające bezpieczeństwo, przy uwzględnieniu najtrudniejszych przewidywalnych warunków eksploatacji i ewakuacji, biorąc pod uwagę ruch pionowy, wzdłużny $\mathrm{i}$ poprzeczny pojazdów,

- Maksymalne odległości pomiędzy pojazdami a ziemią $\mathrm{w}$ zależności od charakterystyki technicznej systemu, typu pojazdu i procedur ewakuacyjnych, przy czym przy projektowaniu pojazdów należy wziąc pod uwagę aspekt psychologiczny,

- Maksymalna prędkość pojazdów, minimalną odległość między nimi oraz ich przyspieszenia i opóźnienia zapewniające bezpieczeństwo osób oraz bezpieczne działanie systemu.

Zakładane bezpieczeństwo PRT wynika przede wszystkim z faktu, że inteligentny pojazd nie wymaga obecności w nim operatora i tym samym liczba ewentualnych pomyłek popełnionych przez czynnik ludzki sprowadza się do minimum.

Zalety projektowanego systemu wynikają przede wszystkim z jego specyfiki i można do nich zaliczyć m.in.:
- Łatwość obsługi pojazdu ( dla każdego),

- Krótka, czasowo przewidywalna podróż, bez przystanków pośrednich,

- Czas oczekiwania na pojazd minimalny lub zerowy,

- Podróż na siedząco,

- System dostępny dla pasażera przez całą dobę,

- Pojazdy wyposażone w klimatyzację,

- Podróż komfortowa, najczęściej w gronie znanych sobie osób,

- Zapewnione osobiste bezpieczeństwo,

- Wystarczająco dużo miejsca w pojeździe na bagaż, wózek osoby niepełnosprawnej, rower, czy wózek dziecięcy.

Standardy bezpieczeństwa stosowane w projektowaniu, budowie i eksploatacji systemów PRT są podobne do tych, które mają zastosowanie w przypadku nowoczesnych i inteligentnych pojazdów, a także lotnictwa cywilnego.

\section{Projektowanie ergonomiczne polskiego pojazdu SITIN}

W ergonomicznym podejściu do projektowania należy zwrócić uwagę na aspekt jakości [3]. Zgodnie z ISO 8402 jakość to zespół właściwości i charakterystyk liczbowych systemu lub funkcji wykonywanych przez system, które wpływają na jego zdolność do zaspokajania potrzeb konsumentów/eksploatatorów. Jakość może być inaczej rozumiana jako kombinacja trzech składowych: (1) jakości technicznej (konstrukcyjnej), wyrażanej jako zgodność z wyspecyfikowanymi wymaganiami (w tym bezpieczeństwa), (2) jakości ergonomicznej, zwykle rozumianej jako wygoda obsługi, co w znacznym stopniu wynika ze zgodności interfejsu użytkownika z zaleceniami ergonomicznymi, (3) jakości użytkowej, rozumianej jako użyteczność produktu, która jest bezpośrednio odczuwana i weryfikowana przez użytkownika podczas wykonywania rzeczywistych zadań roboczych. Nie zawsze udaje się zachować równowagę między wymienionymi składowymi jakości. Nie mniej dążymy do tworzenia techniki przyjaznej człowiekowi i środowisku naturalnemu, co wymaga wiedzy

technicznej, ale również wiedzy o człowieku, o jego możliwościach i ograniczeniach w kontakcie $\mathrm{z}$ techniką, o wpływie techniki na środowisko, itd.

Wymiary wewnętrzne kabiny pojazdu SITIN powinny umożliwiać komfortową jazdę $90 \%$ populacji polskiej, tzn. osobom, które z punktu widzenia antropometrii mieszczą się między 5 i 95 centylem $\left(\mathrm{C}_{5}\right.$ a $\mathrm{C}_{95}$ ) oraz osobom poruszającym się na wózkach inwalidzkich. 
W celu zapewnienia bezpieczeństwa osób:

- pojazdy powinny być wyposażone w urzadzenia łączności umożliwiające stały kontakt między użytkownikami a obsługą systemu.

- dostęp do miejsc wsiadania i wysiadania oraz wsiadanie i wysiadanie użytkowników powinny być zorganizowane $\mathrm{z}$ uwzględnieniem ruchu i zatrzymania pojazdów,

- dzieci i osoby niesprawne ruchowo powinny mieć możliwość korzystania $\mathrm{z}$ pojazdów $\mathrm{w}$ sposób bezpieczny.

Konstrukcja pojazdu musi wykluczać możliwość jazdy $\mathrm{z}$ otwartymi drzwiami w warunkach normalnej eksploatacji. Drzwi pojazdów powinny być zaprojektowane i zbudowane $\mathrm{w}$ taki sposób, aby było możliwe ich zamykanie i blokowanie. Okna nie powinny być otwierane na zewnątrz, a ich otwieranie powinno być możliwe tylko $\mathrm{z}$ wnętrza wagonu, (nie dotyczy to okien urządzonych jako wyjścia awaryjne). Elementy wnętrza pojazdu powinny być wykonane $\mathrm{z}$ materiałów dopuszczających czyszczenie na mokro i oddziaływanie środkami dezynfekującymi. Materiały te powinny posiadać minimalne cechy bezpieczeństwa przeciwpożarowego.

Kabina pojazdu powinna być wyposażona w:

- oświetlenie wnętrza włączane i wyłączane samoczynnie lub z centrum sterowania:

$>$ zasadnicze, którego natężenie oświetlenia mierzone na wysokości $850 \mathrm{~mm}$ od podłogi nie powinno być mniejsze niż $100 \mathrm{~lx}$,

$>$ awaryjne, włączające się samoczynnie w razie zaniku napięcia w sieci trakcyjnej, przy włączonym oświetleniu zasadniczym,

- urządzenia zapewniające przewietrzanie i ogrzewanie z możliwością regulacji temperatury,

- fotele do siedzenia przymocowane trwale do konstrukcji pojazdu, posiadające składane (podnoszone ) siedziska i podnoszone podłokietniki,

- podłoga powinna być wykonana z materiału antypoślizgowego.

Pojazd PRT z założenia jest inteligentnym środkiem transportu (prowadzonym automatycznie bez operatora). Podróż odbywa się od stacji początkowej do stacji docelowej bez przystanków pośrednich. Zatem kabina powinna być wyposażona w urządzenie umożliwiające pasażerowi wybór docelowego przystanku.

\section{Ksztalt i wymiary pojazdu SITIN}

Biorąc pod uwagę indywidualny charakter tego transportu i poruszanie się pojazdów po lekkiej infrastrukturze, w fazie projektowania kształtu założono, że pojazd powinien być lekki i małych rozmiarów. Ponadto, powinien odejść formą od kształtu typowego dla już użytkowanych środków transportu i nie powodować skojarzeń z górskimi kolejkami linowymi. Zaprojektowana forma powinna być na tyle charakterystyczna, aby w przyszłości mogła stać się rozpoznawalna i identyfikowana z tym właśnie środkiem transportu miejskiego. Ważne było też znalezienie kształtu, który jednocześnie podkreślałby nowoczesność i odmienność tego rodzaju transportu, ale także wpisywał się w krajobraz miejski i dodatkowo nie był odbierany jako ,intruz”. W procesie doboru kształtu przeanalizowano różne rozwiązania i zdecydowano, że we wstępnych badaniach kształtem wyjściowym projektu będzie elipsa. Ze względu na specyfikę opisywanego rodzaju transportu istotnym zagadnieniem stała się kwestia zachowania odpowiednich proporcji pomiędzy połaciami nieprzezroczystymi a przeszkleniami, co uczyniło pojazd PRT przyjazny dla użytkownika oraz zapewniający mu poczucie bezpieczeństwa. (rys.1)

Ostateczne wymiary pojazdu determinowane były przez wiele czynników, np. jak już wspomniano, indywidualność transportu, a także możliwość korzystania $z$ niego przez osoby niepełnosprawne. $Z$ danych statystycznych wynika, że w Polsce żyje około 4 milionów osób niepełnosprawnych, $\mathrm{z}$ czego 75\% stanowią osoby z dysfunkcją narządu ruchu. Populację osób niepełnosprawnych charakteryzuje większe zróżnicowanie cech psychofizycznych w stosunku do populacji standardowej. Środki transportu, a szczególnie te nowoprojektowane powinny uwzględniać szeroki dostęp do ich użytkowania, niezależnie od stopnia sprawności człowieka. Tak więc pojazd PRT-SITIN zaprojektowano do przewozu max 4 osób jednocześnie lub osoby niepełnosprawnej korzystajacej z wózka inwalidzkiego oraz osoby jej towarzyszącej.

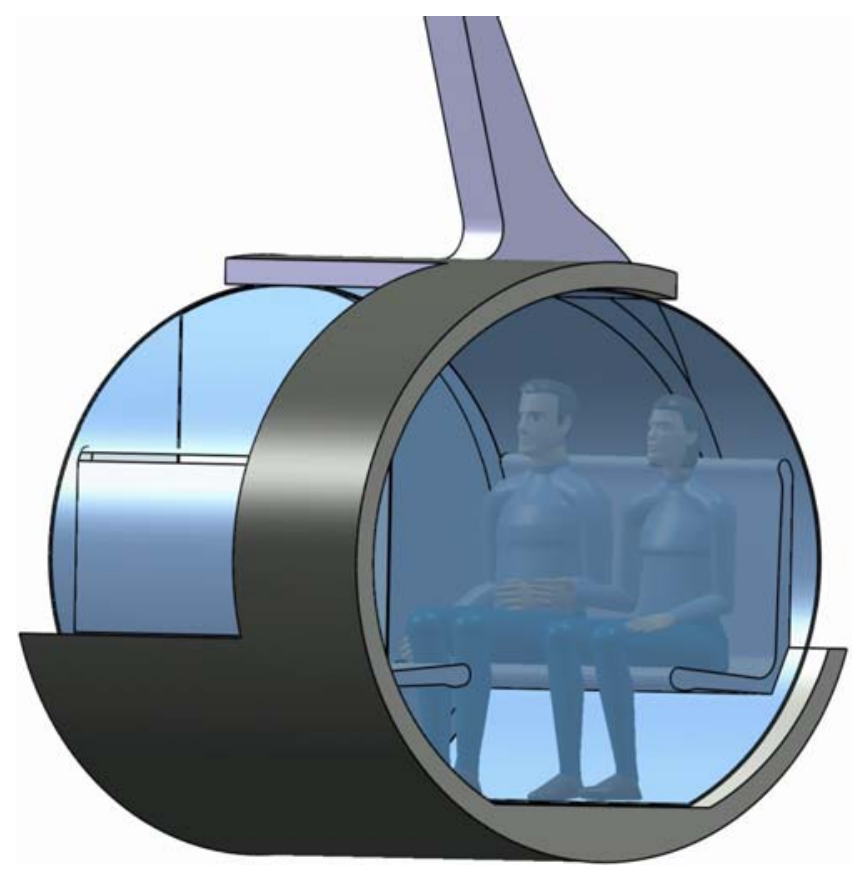

Rys.1. Wstępna wizualizacja pojazdu PRT w programie Catia 
Analiza wymiarów kabiny została przeprowadzona w oparciu o procedurę weryfikacji antropometrycznej, przy czym wykorzystano dwa źródła danych, tzn. Atlas antropometryczny dorosłej ludności Polski autorzy Batogowska A., Słowikowski J., oraz Atlas miar człowieka. Dane do projektowania i oceny ergonomicznej. - autor Gedliczka A.

Część wymiarów zdeterminowana została dostosowaniem pojazdu dla osób niepełnosprawnych, np. szerokość kabiny i szerokość drzwi pojazdu.

Na podstawie badań wstępnych wymiary gabarytowe wynoszą:

Max długość pojazdu $2360 \mathrm{~mm}$

Max wysokość pojazdu (bez ramienia) $1960 \mathrm{~mm}$ Całkowita wysokość pojazdu wraz z ramieniem

$2660 \mathrm{~mm}$

Na rys. 2 i 3 przedstawiono przekroje kabiny pojazdu SITIN w dwóch rzutach.

Długość ramienia uwarunkowana jest względami bezpieczeństwa i powinna uniemożliwiać człowiekowi dotknięcie do szyny. Zatem nie powinna być mniejsza

niż $540 \mathrm{~mm}$. W proponowanym rozwiązaniu wartość ta wynosi $700 \mathrm{~mm}$, co było podyktowane względami bezpieczeństwa jak i rozwiązaniem układu jezdnego. Przyjęcie

ostatecznego rozwiązania układu „szyna - koło” może zmodyfikować tę wartość, dla której granicą dolną jest wartość $540 \mathrm{~mm}$.

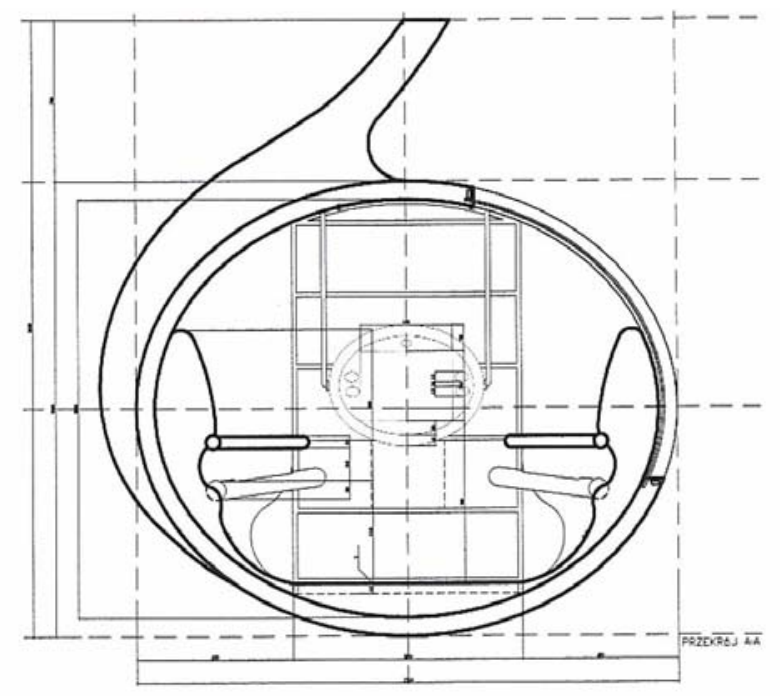

Rys.2. Przekrój kabiny w płaszczyźnie pionowej - oś wzdłużna

\section{Wnioski}

Projektowanie nowych, niekonwencjonalnych środków transportu jest zagadnieniem interdyscyplinarnym. Wymaga rozwiązania wielu problemów i skorelowania ich ze soba. Sformułowanie wymagań z zakresu ergonomii i bezpieczeństwa oraz zastosowanie ich $\mathrm{w}$ fazie koncepcyjnej jest niezwykle istotne

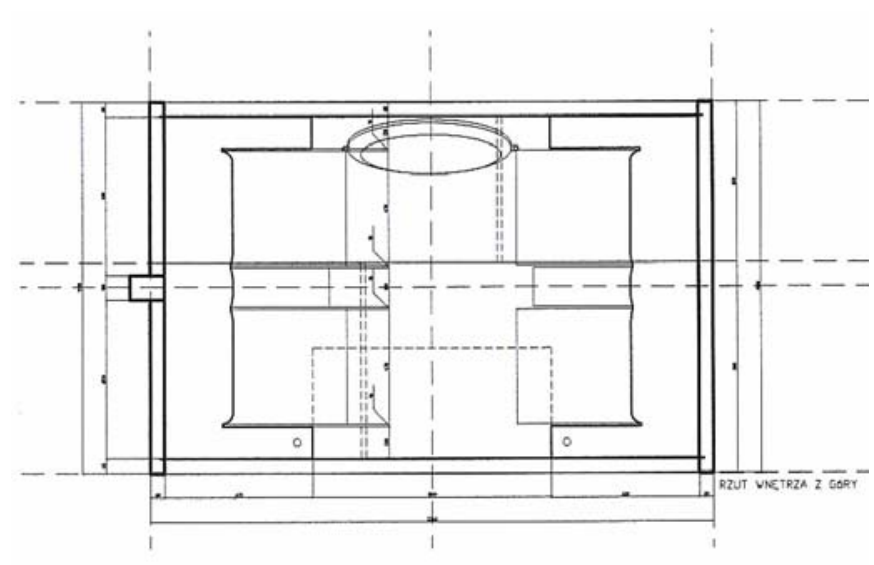

Rys.3. Przekrój poziomy kabiny pojazdu

dla zapewnienia niezawodnego, bezpiecznego i komfortowego transportu pasażerów, w tym także osób niepełnosprawnych. $\mathrm{W}$ artykule zasygnalizowano jedynie wybrane zagadnienia, które należy uwzględnić przechodząc od koncepcji do projektu pojazdu PRT. Pozostałe problemy, nie mniej istotne, będą rozwiązywane $\mathrm{w}$ kontynuowanych pracach projektowych .

\section{Literatura}

[1] Anderson J.E.: The future of High - Capacity PRT, Advanced Automated Transit Systems Conference, Bologna, Italy, November 7-8, 2005

[2] Batogowska A., Stowikowski J.: Atlas antropometryczny dorosłej ludności Polski dla potrzeb projektowania. Prace i materiaty, zeszyt 149, IWP, Warszawa, 1994,

[3] Gedliczka A.: Atlas miar człowieka. Dane do projektowania $i$ oceny ergonomicznej. CIOP, Warszawa 2001,

[4] Jabłoński J. /pod red./: Ergonomia produktu. Wyd. politechniki Poznańskiej, 2006

[5] Sprawozdanie z realizacji Uczelnianego Projektu Badawczego (Grant J.M Rektora Politechniki Warszawskiej) nt ,Modelowanie i Badania Symulacyjne Inteligentnego Miejskiego Indywidualnego Systemu Transportu Elektryczno -Rolkowego - Mister" - Kierownik projektu W. Choromański Politechnika Warszawska 2007. 